\title{
Characterization and Evaluation of the Potential Uses of Mouyondzi Clay
}

\author{
Joseph Marie Moutou',2, Paul Mozalin Foutou1, Laurent Matini1,2, Vivien Banzouzi Samba1, \\ Zita Flora Diamouangana Mpissi ${ }^{1}$, Raunel Loubaki ${ }^{1}$ \\ ${ }^{1}$ Laboratoire de Chimie Minérale Appliquée, Faculté des Sciences et Techniques, Université Marien Ngouabi, Brazzaville, Congo \\ ${ }^{2}$ Ecole Normale Supérieure, Université Marien Ngouabi, Brazzaville, Congo \\ Email: jmsbmout@yahoo.fr
}

How to cite this paper: Moutou, J.M., Foutou, P.M., Matini, L., Samba, V.B., Mpissi, Z.F.D. and Loubaki, R. (2018) Characterization and Evaluation of the Potential Uses of Mouyondzi Clay. Journal of Minerals and Materials Characterization and Engineering, 6, 119-138.

https://doi.org/10.4236/jmmce.2018.61010

Received: August 23, 2017

Accepted: January 28, 2018

Published: January 31, 2018

Copyright $\odot 2018$ by authors and Scientific Research Publishing Inc. This work is licensed under the Creative Commons Attribution International License (CC BY 4.0).

http://creativecommons.org/licenses/by/4.0/

\begin{abstract}
The overall goal of this study is to characterize and to evaluate the potential uses of clay mined in the Nzaou locality. The Mou sample is argillaceous texture and medium plasticity ( $\mathrm{Ip}=28.9$ ). Kaolinite is dominant clay species $(44.41 \%)$. It is associated with illite (9\%). Quartz and rutile are the main non clay minerals. The CEC is $8.66 \mathrm{cmol}+/ \mathrm{kg}$. Organic matter is low $(0.839 \%)$. Total shrinkage obtained by dilatometry at $1200^{\circ} \mathrm{C}$ is $9.26 \%$. The chemical and mineralogical compositions have allowed using the ternary diagrams of Fabbri and Fiori that the MOU clay is favorable for glazed white stoneware (GWS) and for the production of clinker (KLK). Dondi typologies of ceramic tiles according to body color (mostly depending on the iron oxide content) and compactness (expressed by water absorption) have confirmed the use for the manufacture of the GWS and clinker. Classification always according to Dondi taking into account the rate of kaolinite, the fine fraction $(<2 \mu \mathrm{m})$ and plasticity index gives MOU clay to be considered as medium ball clays $(\mathrm{BC} 1)$. The absorption rate indicates that the body fired at $1200^{\circ} \mathrm{C}$ will be vitrified. Flexural strength at $1200^{\circ} \mathrm{C}(16 \mathrm{MPa})$ does not correspond to the requirements of GWS or a clinker.
\end{abstract}

\section{Keywords}

Mouyondzi Clay, Mineralogy, Technological Properties, Potentiality, Ceramic Tiles

\section{Introduction}

Clays are used as raw materials in many industrial fields (ceramic, paper, paint, oil industry, clarification of various effluents, catalysis.) [1]. Their applications 
are closely dependent on their structure, composition and physical characteristics [2]. The knowledge of these characteristics can help for best exploitation and eventually may open up new areas of application [3]. The clay of Loutete is used by craftsmen in the manufacture of fired bricks. Mineralogical, physical, and chemical characterization as well as technological testing revealed that this clay can be used to more interesting purposes such as the production of ceramic tiles [4]. Knowledge of these properties is important for understanding the technology of production of ceramic and firing cycles optimization [5]. The assessment of the possible applications of the Triassic in ceramic earthenware clays were based on the chemical, mineralogical and technological results [3]. As a basis for the development of ceramics, the selection of the raw materials plays a fundamental role in the design of the final product. For an effective selection of materials, the knowledge on all the properties of the raw materials must be obtained. Plasticity is one of the most important properties for molding of products in clay [6]. Dondi et al. have studied the chemical, mineralogical composition and technological behavior that allow the evaluation of the applicability of the clays in ceramic [7]. A relative important deposit of clay in the Department of Bouenza (Congo Brazzaville), specifically in the locality of Nzaou, is exploited for the manufacture of clay products consumed by geophagy. Although in the surrounding regions (Loutete, Madingou), clay served in ceramic productions (pottery, fired bricks), no attempt has been reported on the Nzaou deposit clay. A detailed characterization of this clay is necessary to justify the absence of use in ceramics or identify possible areas of application.

The objective of this study is to carry out mineralogical, physical and chemical characterization and determine the technological properties of the Nzaou clay (MOU).

So, we will try to define the possibilities of use of Nzaou clay (MOU).

\section{Materials and Experimental Methods}

\subsection{Material and Geological Settings}

The sampling site is located in the Department of Bouenza (Republic of Congo), in the district of Mouyondzi precisely to the Nkengue village about $10 \mathrm{~km}$ from Mouyondzi locality (Figure 1) [8].

The valley of Niari in which the department of Bouenza is situated, presents soils, the mother rock of which consists in schisto-limestones represented by pink and grey dolomites, clayey limestones, built limestones and crystalline limestones, stony sands, sandy and siliceous limestones and finally by grey dolomites on oolitic levels [9]. The Mouyondzi district falls around latitude $3^{\circ} 30^{\prime}$ and $4^{\circ}$ of the equator and longitude $13^{\circ} 30^{\prime} \mathrm{E}$ and $14^{\circ} \mathrm{E}$ of Greenwich meridian. Mouyondzi district is located on clay soils highly truncated by erosion, strongly leached, restructured and yellow clayey silt soils moderately leached coming from schisto-limestones [10]. Nzaou deposit clay is widely consumed by pregnant women and used by traditional therapists for the treatment of various dis- 


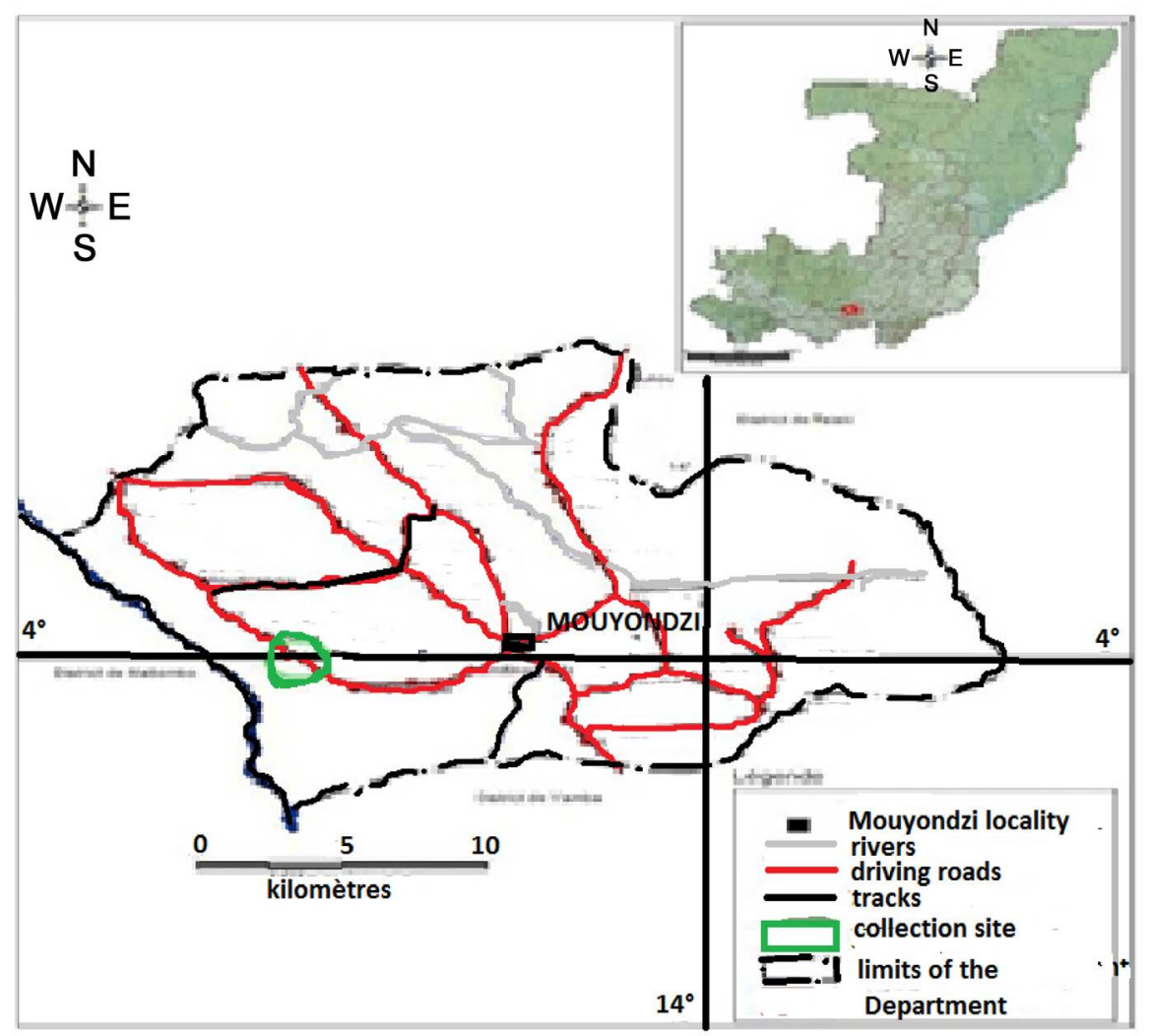

Figure 1. Localization of sampling site.

eases (gastric problems, wounds). About 1 meter deep holes were dug to collect clay. It is at this depth that the samples have been collected and air-dried in the laboratory.

\subsection{Experimental Methods}

\subsubsection{Geotechnical Characterization}

The plasticity was measured by the Atterberg indices: Liquid Limit (LL), Plastic Limit (PL) and Plastic Index (PI) according to the norm NF P 94-051 [11]. Particlesize analysis was performed at the laboratory of soils (LAS) according to the NF X 31-107 [12].

\subsubsection{Mineralogical Characterization}

The XRD of sample powder was performed using a Philips model diffractometer operating by reflection under the $\mathrm{Cu}-\mathrm{K} \alpha$ radiation for $2 \theta$ angle ranging from $5^{\circ}$ to $60^{\circ}$.

Diffuse Reflectance Infra-red Fourier Transform Spectroscopy (DRIFTS) was performed over a wave number domain between 600 and 4000 per $\mathrm{cm}$ using a Bruker IFS 55 spectrometer equipped with a broad band detector of the type MCT (Mercury and Cadmium Tellurium) cooled with $77 \mathrm{~K}$ and with an accessory of diffuse reflection (Harrick Corporation). The powdered sample was diluted in $\mathrm{KBr}$ ( $50 \mathrm{mg}$ of sample in $350 \mathrm{mg}$ of $\mathrm{KBr}$ ). The spectra were recorded by accumulating 200 scans at 2.0 per $\mathrm{cm}$ resolution. 
The Differential Thermal Analysis (DTA) and Thermo Gravimetry (TGA) were carried out with a device coupled with a thermobalance and a mass spectrometer THERMOSTAR. The speed of heating was $10^{\circ} \mathrm{C} / \mathrm{mn}$. The dilatometric analysis was performed using a NETZSCH 402 ED horizontal differential dilatometer-internal Code: DI 1 with, for reference, a bar in dense alumina (purity 99.5\%). The unit is equipped with the PROTEUS analysis and treatment software. The test specimen was obtained by application an vertical axial pressure of $20 \mathrm{kN}$ into a $5 \times 5 \times 50 \mathrm{~mm}$ stainless mould on a manual hydraulic press $\left(\mathrm{P}_{\max }=\right.$ $230 \mathrm{kN}$ ). Then pressed piece is cut for a vial of test size: (section $5 \times 5 \mathrm{~mm}$, length: $5 \mathrm{~mm}$ measured with caliper with $0.01 \mathrm{~mm}$ accuracy) the thermal cycle is: $5^{\circ} \mathrm{C} / \mathrm{min}$ up to $1200^{\circ} \mathrm{C}$, level of 2 hours and cool down lies at $5^{\circ} \mathrm{C} / \mathrm{min}$

\subsubsection{Chemical Characterization}

The chemical analysis of the major elements was carried out in the Center of Petrographic and Geological Research (CRPG) Nancy according to Carignan et al. [13].

Organic matter: the total organic carbon and total nitrogen have been determined by method described by the norms NF ISO 10694 and 13878 [14] in soil analysis laboratory (LAS) of INRA (Arras).

Cationic exchange capacity is measured by Metson method NF X 31-130 [15].

\subsubsection{Technological Properties}

1) Preparation and firing of the test samples: $10 \mathrm{~g}$ and $45 \mathrm{~g}$ of clay powder were mixed respectively with 10 and $5 \mathrm{~mL}$ of distilled water in a porcelain mortar and then put respectively in cylindrical and parallelepiped steel mould. An axial vertical pressure of $342 \mathrm{MPa}$ was applied to obtain two types of test specimens:

- Discs of $4 \mathrm{~mm}$ diameter and $6 \mathrm{~mm}$ in thickness in order to measure the physical properties (open porosity, gross density and water absorption)

- Parallelepiped test specimens for the determination of linear firing shrinkage and flexural strength

The test specimens obtained were first dried at $110^{\circ} \mathrm{C}$ for $24 \mathrm{~h}$ and then fired at $1000^{\circ} \mathrm{C}, 1050^{\circ} \mathrm{C}, 1100^{\circ} \mathrm{C}$ and $1150^{\circ} \mathrm{C}, 1200^{\circ} \mathrm{C}$ and $1250^{\circ} \mathrm{C}$ in a NABERTHERM model kiln with a heating rate of $5^{\circ} \mathrm{C} / \mathrm{mn}$ and a $2 \mathrm{~h}$ evaluation time.

2) Determinations of technological properties: The linear shrinkage, open porosity, bulk density and water absorption were measured according to the protocol P18-554 of the French norms [16]. The flexural strength was determined by the three points method [17] [18] with an electrohydraulic press (M\&O, type $11.50 \mathrm{~N}^{\circ} 21$ ).

\section{Results and Discussion}

\subsection{Geotechnical Properties}

Table 1 gives us the grain size distribution and Atterberg limits of Mou sample. 
The use of USDA texture triangle [19] (Figure 2) has allowed assigning a clayey texture to the MOU sample.

The positioning of the MOU clay in the Winkler triangle [20] is given by Figure 3.

The grain-size distribution of MOU is not favorable for the manufacture of structural ceramics (tiles, bricks, hollow with thin walls, bricks with vertical perforation and full bricks).

The Atterberg limits values of MOU lead us to set MOU sample at the limit between the medium plastic inorganic clay and the high plastic inorganic clay in the Casgrande abacus [21] (Figure 4).

Located between the areas of montmorillonite and illite in the diagram of Holtz and Kovacs [22] (Figure 5), we think that MOU would be a mixture of clays species (illites and kaolinite and montmorillonite).

Table 1. Geotechnical properties of MOU sample.

\begin{tabular}{|c|c|c|c|c|c|}
\hline \multirow[t]{2}{*}{ Granulométrie } & $\begin{array}{l}\text { Argiles } \\
<2 \mu \mathrm{m}\end{array}$ & $\begin{array}{c}\text { Limons fins } \\
(2 / 20 \mu \mathrm{m})\end{array}$ & $\begin{array}{l}\text { Limons grossiers } \\
\qquad(20 / 50 \mu \mathrm{m})\end{array}$ & $\begin{array}{l}\text { Sables fins } \\
(50 / 200 \mu \mathrm{m})\end{array}$ & $\begin{array}{c}\text { Sables grossiers } \\
(200 / 2000 \mu \mathrm{m})\end{array}$ \\
\hline & $65 \%$ & $20.9 \%$ & $8.1 \%$ & $3.6 \%$ & $2.4 \%$ \\
\hline \multirow{2}{*}{ Limites d'Atterberg } & \multicolumn{2}{|c|}{ Limite de Liquidité } & \multicolumn{2}{|c|}{ Limite de Plasticité } & lice de plasticité \\
\hline & \multicolumn{2}{|r|}{51.2} & \multicolumn{2}{|l|}{22.3} & 28.9 \\
\hline
\end{tabular}

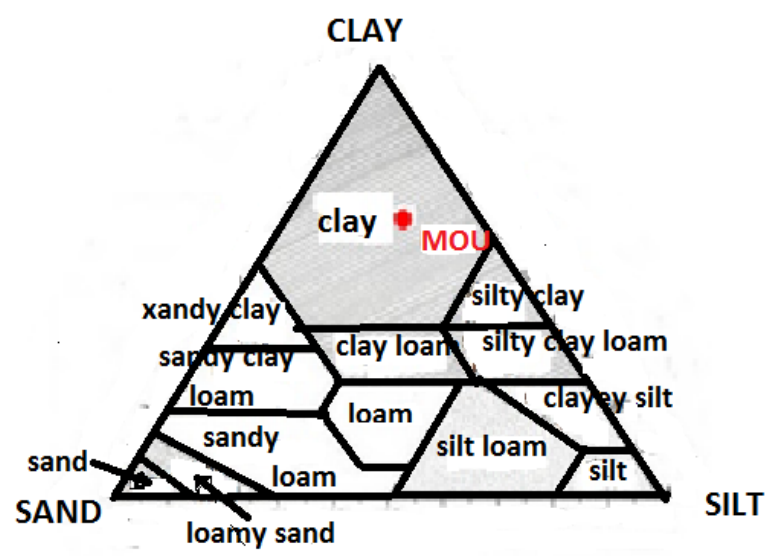

Figure 2. Positioning of MOU sample in USDA texture triangle.

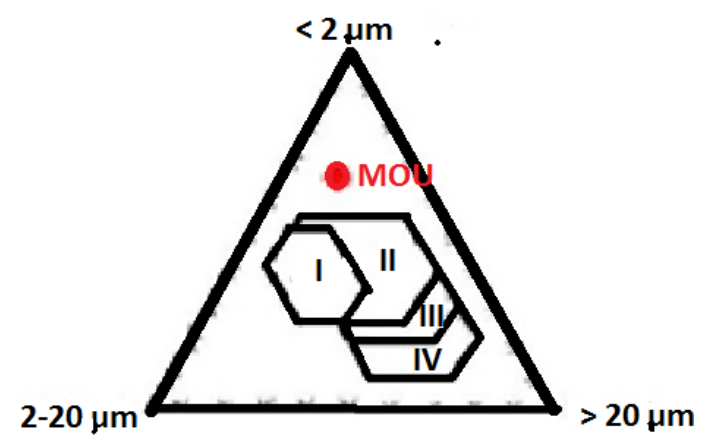

Figure 3. Positioning of MOU sample in Winkler diagram. 


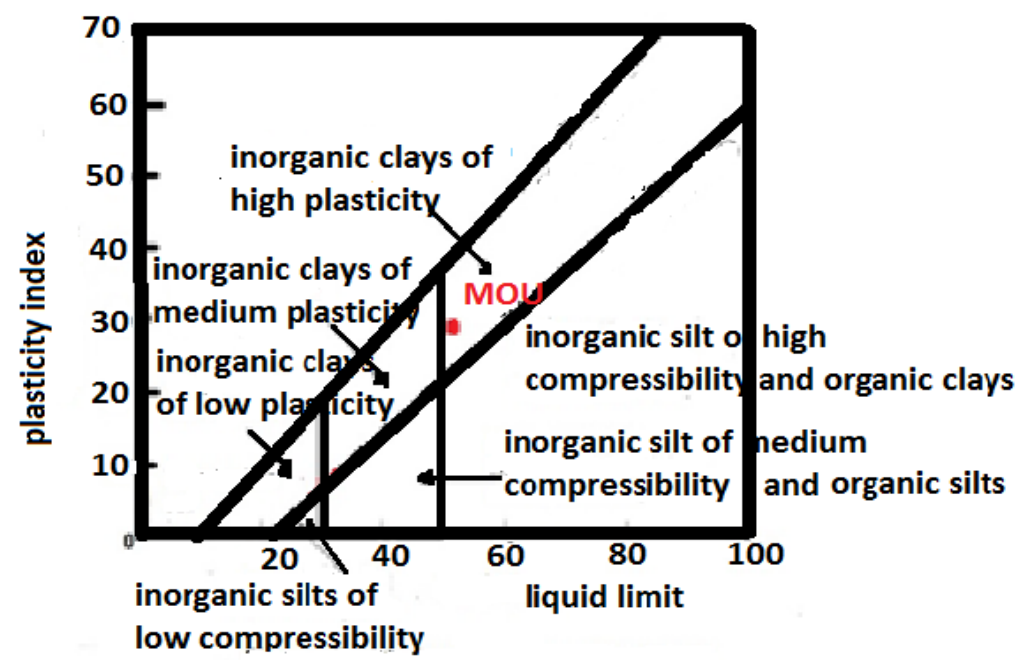

Figure 4. Positioning of MOU sample in Casagrande chart.

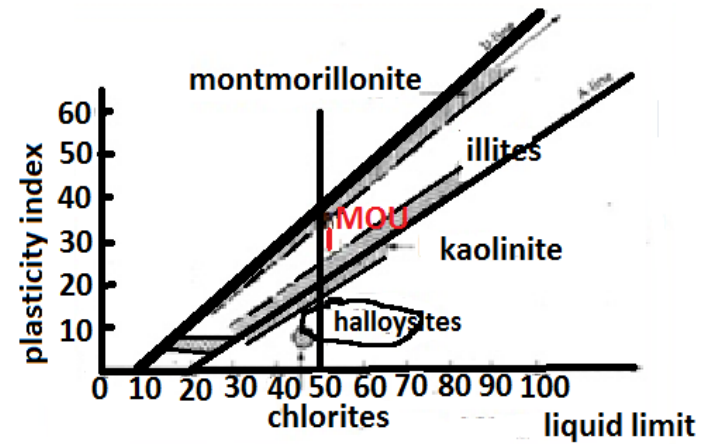

Figure 5. Positioning of MOU sample in Holtz and Kovacs chart.

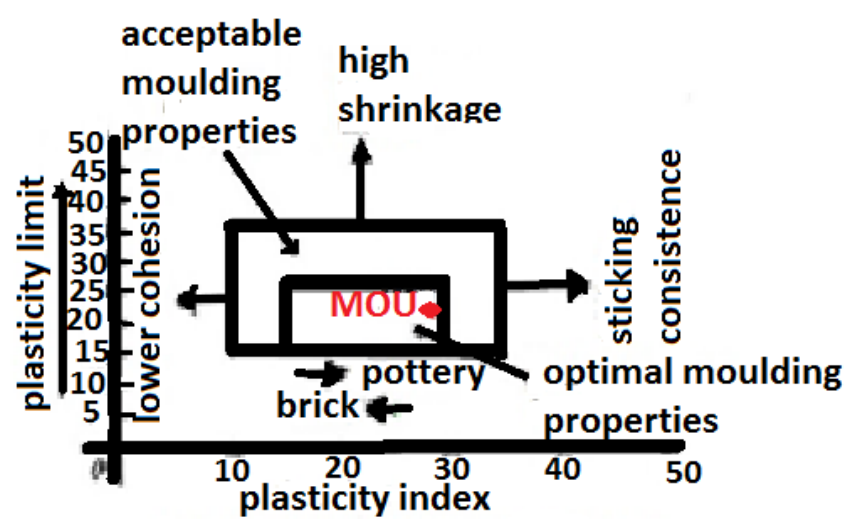

Figure 6. Positioning of MOU sample in workability chart.

MOU clay would present optimal properties of moulding and a relatively weak shrinkage in considering its positioning in the workability chart of Bain and Highly [23] (Figure 6).

\subsection{Mineralogical Characterizations}

\subsubsection{X-Ray Diffraction}

X-ray diffraction pattern of MOU is shown in the Figure 7. 


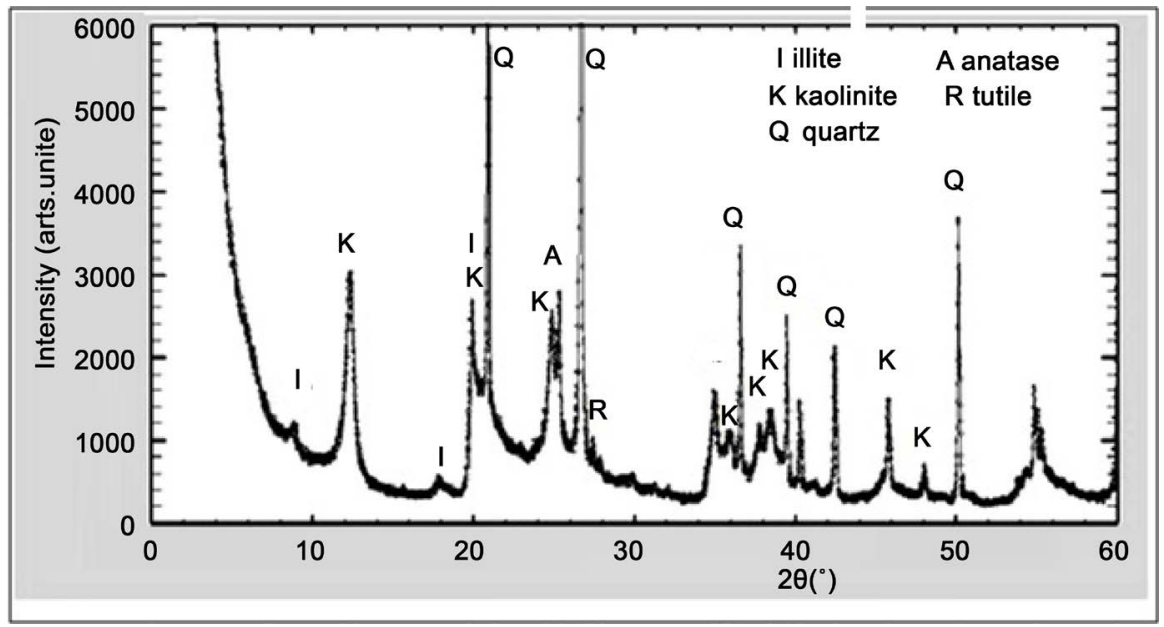

Figure 7. X-ray diffraction pattern of MOU sample.

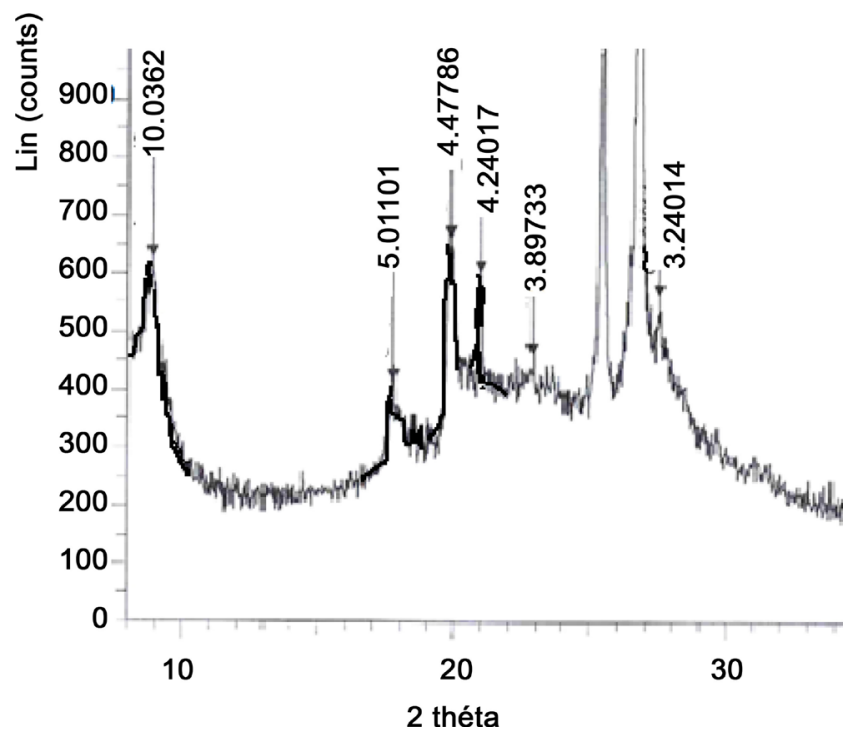

Figure 8. XRD pattern of MOU clay heated to $500^{\circ} \mathrm{C}$.

The analysis of this XRD pattern enabled to detect the presence of the following key minerals: illite, kaolinite and quartz [24]. We had recorded the spectrum $\mathrm{X}$ of MOU clay heated to $500^{\circ} \mathrm{C}$. It is represented in the Figure 8 .

We see the disappearance of the peaks of kaolinite and the persistence of the peaks at $10.03 \AA, 5.01 \AA$ and $4.47 \AA$ characteristics of the illite.

The relatively high intensity of quartz indicates a significant presence of free silica even if the particle size analysis indicates only $6 \%$ of sand. This suggests that the sand is very fine and maybe a part is found in the silt fraction.

The reflection at $3.51 \AA$ indicates the presence of anatase. The peak at $3.24 \AA$ can be associated to rutile.

In the XRD pattern of an ordered kaolinite, the interval ranging from $19^{\circ}$ to $23^{\circ}$ presents usually three distinct peaks while the increase in disorder makes that the sequence of 021,111 reflections in the range $20^{\circ}-33^{\circ}$ becomes increasingly blurred until with halloysite only a smooth diffraction band with the su- 
perimposed 002 basal reflection is obtained [24]. As we observe one peak in this interval, we can think that the kaolinite is disordered.

Considering the heights of characteristic peaks of kaolinite and the muscovite, kaolinite is the most abundant clay mineral.

2-2 Infra-red spectroscopy

The IR of MOU spectrum is represented on Figure 9.

The crystalline structure of kaolinite is constituted of two sheets tetrahedral and octahedral forming a layer [25]. Each octahedron presents four hydroxyl groups and two oxygens in these corners. The four hydroxyl groups consist of two parts: outer hydroxyl groups (03) and inner hydroxyl group [26].

The range of frequencies from $3700 \mathrm{~cm}^{-1}$ to $3100 \mathrm{~cm}^{-1}$ corresponds to stretching modes of $\mathrm{OH}$ groups [26]. The DRIFTS spectrum of MOU sample shows peaks at $3696,3653,3621 \mathrm{~cm}^{-1}$ which are assigned to $\mathrm{OH}$ stretching vibration modes [26] [27] [28]. Normally it should be observed four bands related to four hydroxyl groups when kaolinite is well crystallized. In kaolinite poorly crystalline these bands reduce to three [27]. When the disorder of kaolinite increases, there is the gradual disappearance of the band of valence vibration to $3672 \mathrm{~cm}^{-1}$. An inversion of the intensities of the bands at 3655 and $3672 \mathrm{~cm}^{-1}$ occurs before the disappearance of the band at $3672 \mathrm{~cm}^{-1}$ [29] [30] [31]. The non observation of the $3672 \mathrm{~cm}^{-1}$ band in MOU spectrum suggests that we have a disordered kaolinite.

So, kaolinite in MOU sample is considered as poorly crystalline. This observation corroborates the XRD pattern of MOU. The range from $1200 \mathrm{~cm}^{-1}$ to 600 $\mathrm{cm}^{-1}$ contains frequencies related to modes of deformation of groups $\mathrm{OH}$ [32] [26]. Frost has examined hydroxyl deformations in kaolins. He has observed two bands at 935 and $915 \mathrm{~cm}^{-1}$ in kaolinite IR spectrum [33]. The MOU spectrum shows a band at $915 \mathrm{~cm}^{-1}$ with shoulder at $935 \mathrm{~cm}^{-1}$ which are so attributed at $\mathrm{OH}$ deformation modes. Si-O stretching vibrations occur in the region going from $1150-960 \mathrm{~cm}^{-1}$ [27]. Farmer has noted that in the spectra of the dickite, nacrite and kaolinite of which the crystals have larger dimension $(>2 \mu \mathrm{m})$ this

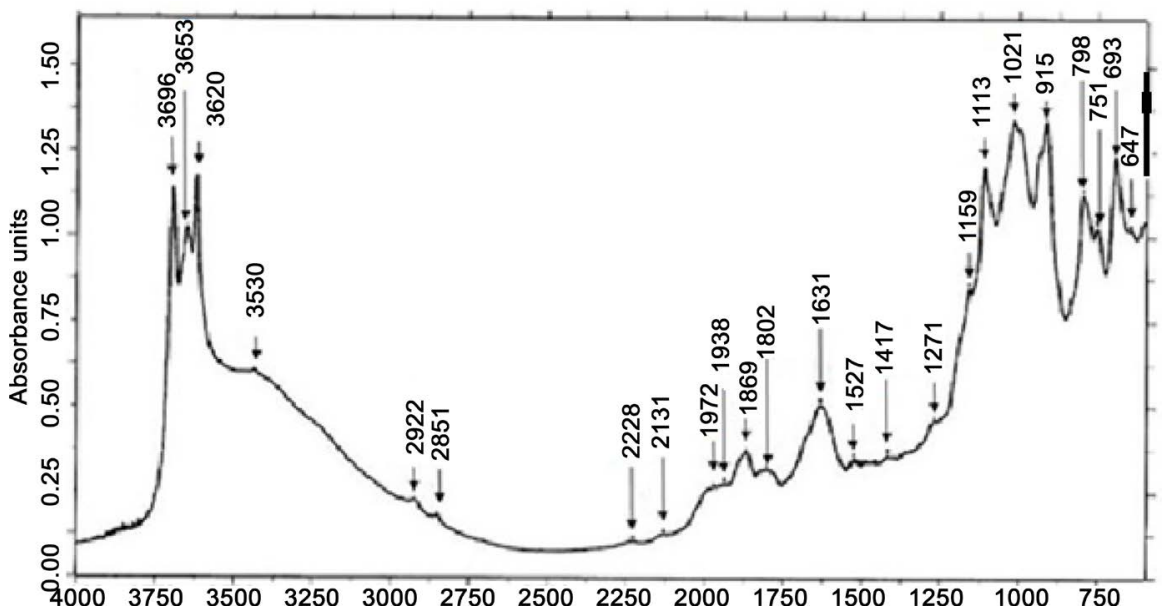

Figure 9. DRITF spectrum of MOU sample. 
mode appears as a shoulder near $1080 \mathrm{~cm}^{-1}$ [27]. This band intensifies and shifts at higher frequencies in spectra of smaller crystals until in very finely ground material the band is close to that found for clay kaolinite $\left(1109 \mathrm{~cm}^{-1}\right)$ [27]. The observation of a band at $1113 \mathrm{~cm}^{-1}$ attributable to Si-O stretching vibration mode is in agreement with the grain-size distribution of MOU sample. The bands at $1159 \mathrm{~cm}^{-1}$ and $1113 \mathrm{~cm}^{-1}$ correspond to Si-O symmetrical and asymmetrical mode. The mode of elongation of the $\mathrm{Si}-\mathrm{O}$ bond in kaolinite gives a band at $1021 \mathrm{~cm}^{-1}$.

The intense bands at 3420 and $1631 \mathrm{~cm}^{-1}$ are due to the molecular water molecules [34] [35]. In TFTIS spectrum at $80^{\circ} \mathrm{C}$ the intensities of these bands highly decrease [4] [36]. The presence of organic matter is supported by the slightly intense bands at 2931 and $2820 \mathrm{~cm}^{-1}$ [28].

The presence of quartz in the sample is manifested by bands at $798 \mathrm{~cm}^{-1}$ (Si$\mathrm{O}$ stretching mode) and $696 \mathrm{~cm}^{-1}$ (deformation mode $\mathrm{Si}-\mathrm{O}$ ) [37]. The $2228 \mathrm{~cm}^{-1}$ band could be attributed to combinations of frequencies (stretching and deformation) of the hydroxyl groups $\mathrm{OH}$ in 2:1 dioctahedral minerals [28] in relation to the presence of illite.

\subsubsection{Thermal Differential and Gravimetric Analysis}

Thermo-gravimetric and thermal differential analysis curves are given in Figure 10.

The following observations are made on the thermo-gravimetric and differential thermal analysis curve data:

- An endothermic peak between $100^{\circ} \mathrm{C}$ and $200^{\circ} \mathrm{C}$, with maximum at approximately $125^{\circ} \mathrm{C}$, corresponding to a loss of mass from $1.257 \%$.

- An endothermic peak important $547^{\circ} \mathrm{C}$, accompanied by a mass loss of $8.18 \%$.

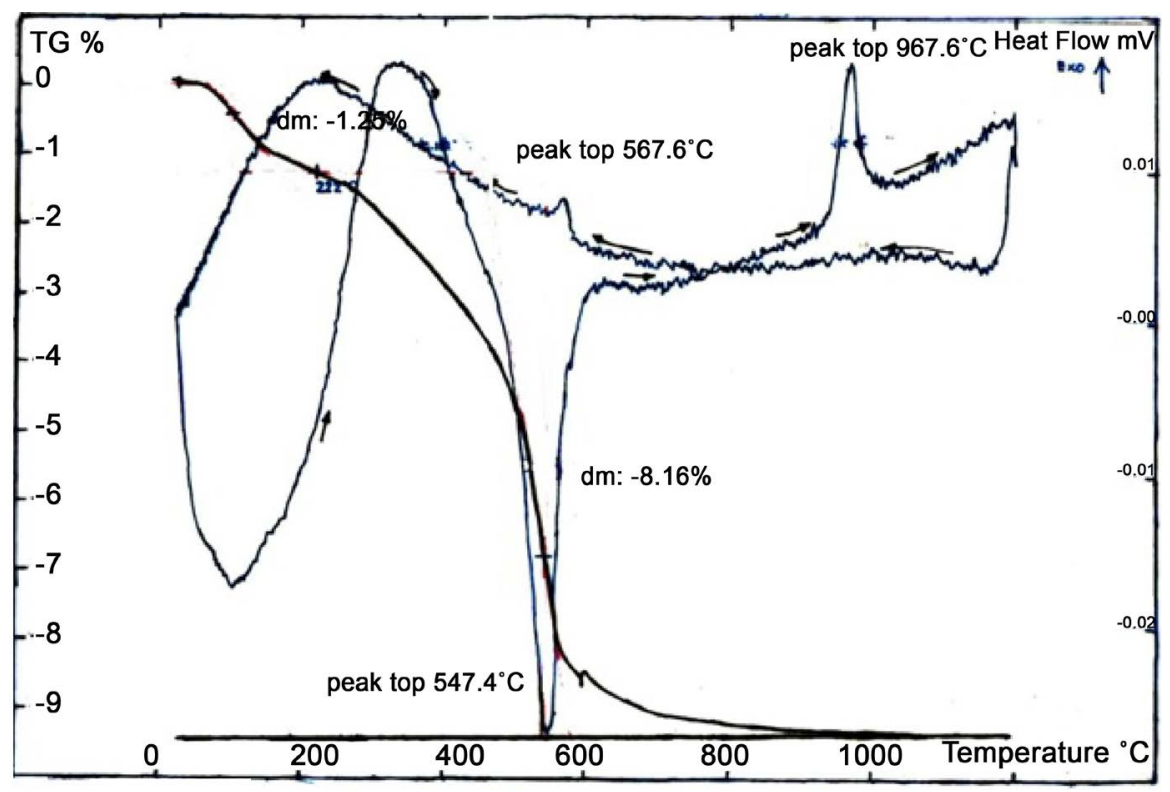

Figure 10. ATD/ATG curves of MOU sample. 
- An exothermic peak around $967^{\circ} \mathrm{C}$.

The peak around $125^{\circ} \mathrm{C}$ corresponds to the departure of water physically adsorbed to the surface of the particles [38]. The allure of the thermogram from $227^{\circ} \mathrm{C}$ up to about $500^{\circ} \mathrm{C}$ presents some irregularity. This suggests an overlap of two phenomena. Between $200^{\circ} \mathrm{C}$ and $400^{\circ} \mathrm{C}$, it is likely that we are witnessing the departure of $\mathrm{CO}_{2}$ due to the combustion of organic matter. In a previous study on the clay taken from Loutete, analysis of the emitted gases indicates the departure of $\mathrm{CO}_{2}$ between these temperatures [4]. The rate of organic materials $(0.367 \%)$ in the sample taken from Loutete is lower than that of the sample Mou (0.839\%) (Table 2$)$. In this same interval, many works indicates the dehydroxylation of goethite [39] [40] [41]. This is less likely because no peak of the goethite were observed on the MOU diffraction pattern. The effect of departure of the $\mathrm{CO}_{2}$ would be upon the origin of the irregularity on the ATD/ATG curves.

The second endothermic peak observed around $547^{\circ} \mathrm{C}$ corresponds to the dehydroxylation of kaolinite where structure water was eliminated following a broadcast mechanism resulting in the formation of amorphous material (metakaolin) [38] [42]. The mass loss associated with this second phenomenon is important (8.18\%). This high loss would imply an abundance of kaolinite.

The exothermic peak at $967^{\circ} \mathrm{C}$ corresponds to the structural reorganization of the metakaolin that turns into mullite. And this temperature is very close to that indicated in cases of presence of iron $\left(980^{\circ} \mathrm{C}\right)$ [42].

During cooling, the ATD curve shows an exothermic lump of low amplitude at $567.2^{\circ} \mathrm{C}$ corresponding to the reversible quartz $\beta$-quartz $\alpha$ transition and confirms the presence of quartz. This transition was not observed during heating. This could be explained by an high abundance of kaolinite.

\subsection{Chemical Properties}

\subsubsection{Chemical Analysis}

The results of the chemical analysis are reported in Table 2.

The $\mathrm{SiO}_{2} / \mathrm{Al}_{2} \mathrm{O}_{3}$ ratio is equal to 2.93. This ratio much higher than in kaolinite indicates a relatively abundant presence of quartz in the clay soil. The $\mathrm{Fe}_{2} \mathrm{O}_{3}$ content is relatively low.

The Fe content having reacted with the Mehra-Jackson reagent (free iron) corresponds to $0.098 \%$. Therefore $\mathrm{Fe}_{2} \mathrm{O}_{3}$ represents $0.14 \%$. Then about $1.36 \%$ of

Table 2. Chemical properties of MOU sample.

\begin{tabular}{|c|c|c|c|c|c|c|c|c|c|c|}
\hline $\mathrm{SiO}_{2}$ & $\mathrm{Al}_{2} \mathrm{O}_{3}$ & $\mathrm{Fe}_{2} \mathrm{O}_{3}$ & $\mathrm{MnO}$ & $\mathrm{MgO}$ & $\mathrm{CaO}$ & $\mathrm{Na}_{2} \mathrm{O}$ & $\mathrm{K}_{2} \mathrm{O}$ & $\mathrm{TiO}_{2}$ & $\mathrm{P}_{2} \mathrm{O}_{5}$ & P.F. \\
\hline 61.45 & 20.96 & 1.5 & 0 & 0.59 & 0.31 & 0.05 & 1.15 & 2.36 & $<$ L.D. & 10.5 \\
\hline \multirow{2}{*}{\multicolumn{2}{|c|}{$\begin{array}{c}\text { Matière } \\
\text { organique }\end{array}$}} & \multicolumn{3}{|c|}{ Carbone organique } & \multicolumn{3}{|c|}{ Azote total } & \multicolumn{3}{|c|}{ Matière organique } \\
\hline & & \multicolumn{3}{|c|}{$0.485 \%$} & \multicolumn{3}{|c|}{$0.047 \%$} & \multicolumn{3}{|c|}{$0.839 \%$} \\
\hline \multicolumn{2}{|c|}{ CEC } & \multicolumn{9}{|c|}{$8.66 \mathrm{cmol}+/ \mathrm{kg}$} \\
\hline \multicolumn{3}{|c|}{ Fe Tamm } & \multicolumn{2}{|c|}{ Al Tamm } & \multicolumn{3}{|c|}{ Fe Mehra-Jackson } & \multicolumn{3}{|c|}{ Al Mehra-Jackson } \\
\hline \multicolumn{2}{|r|}{$0.05 \%$} & & \multicolumn{2}{|c|}{$0.059 \%$} & \multicolumn{3}{|c|}{$0.098 \%$} & \multicolumn{3}{|c|}{$0.085 \%$} \\
\hline
\end{tabular}


$\mathrm{Fe}_{2} \mathrm{O}_{3}$ comes from structural iron. Soro indicates that the iron not reacting to corresponds to structural iron [43].

Indeed many works indicated the substitution of the $\mathrm{Al}^{3+}$ by $\mathrm{Fe}^{3+}$ in kaolinite [42] [44]. In the illites, silica is substituted by $\mathrm{Mg}^{2+}, \mathrm{Fe}^{2+}$ or $\mathrm{Fe}^{3+}$ [2] [25].

The structural $\mathrm{Fe}$ is considered as proof of the disorder. The presence of structural iron in MOU would be so related to low crystallinity of kaolinite.

The coloring oxides ( $\mathrm{Fe}$ and $\mathrm{Ti}$ ) rate (3.86\%) suggests a colored fired body. The percentage of potassium (1.15\%) could come from the presence of the illite. The alkaline earth metal with the total content of $0.9 \%$ may match these carbonates.

\subsubsection{Mineralogical Composition}

The mineralogical composition deduced from chemical analysis and XRD by using the follow formula [30] [45].

$$
T_{(a)}=\sum_{i} M_{i} P_{i}(a)
$$

with:

$T_{(a)}=$ mass percent of the element oxyde "a" in the sample.

$M_{i}=$ mass percent of the mineral " $i$ " in the studied material.

$P_{i}(a)=$ massic amount of the oxyde of the "a" element in the mineral " $\mathrm{i}$ ".

deduced from the ideal formula of the minéral " $\mathrm{i}$ ".

Considering the results of Mehra-Jackson Fe, we have neglected the oxides of iron.

The first estimation of mineralogical composition based on the results of the chemical analysis leads $6.21 \%$ of indeterminate (Table 3 ).

The weight loss associated with the dehydroxylation of kaolinite is $8.16 \%$. Therefore from ATG, the rate of kaolinite is estimated at $52.62 \%$. By integrating the kaolinite rate deducted from the ATG, we greatly reduce the rate of the indeterminate (1.15\%) (Table 3$)$.

Figure 11 gives us the positioning of MOU in ternary diagrams used by Fabbri and Fiori [46] taking into account the chemical composition of the clayey materials used in the production of ceramic tiles. Figure 12 corresponds to the ternary diagram on the mineralogical composition [46]. From these diagrams, MOU clay could be used as white stoneware and in the manufacture of klinker.

\subsection{Dilatometry}

The dilatometric curve of MOU sample is given in the Figure 13.

Table 3. Estimation of mineralogical composition (\%).

\begin{tabular}{ccccccccc}
\hline Echant & kaolinite & illite & talc & quartz & anatase & Hématite & $\Sigma m$ & indéter \\
\hline Mou & 44.41 & 9.58 & 36.26 & 2.36 & & 92.61 & 6.21 \\
Mou & 52.62 & 9.58 & 33.21 & 2.36 & & 97.77 & 1.15 \\
\hline
\end{tabular}




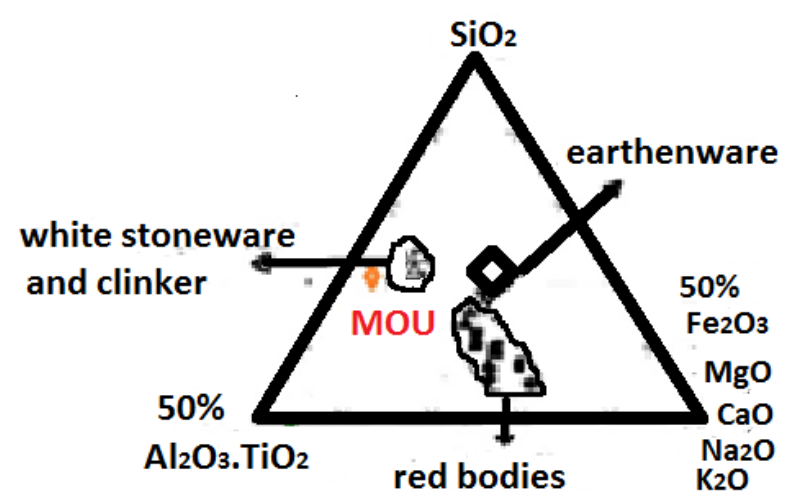

Figure 11. Positioning of MOU sample in the ternary diagram (chemical composition) after Fioi et al. (1989).

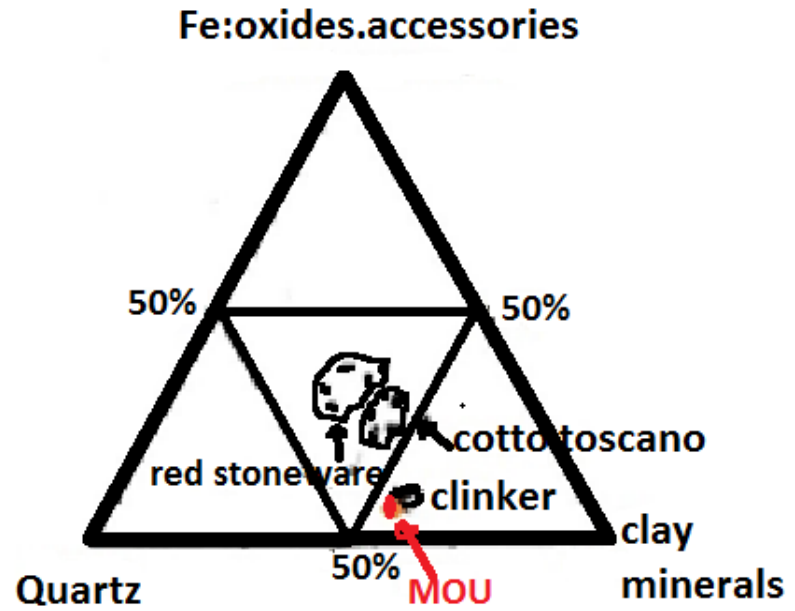

Figure 12. Positioning of MOU sample in the ternary diagram (mineralogical composition) after Fiori et al. (1989).

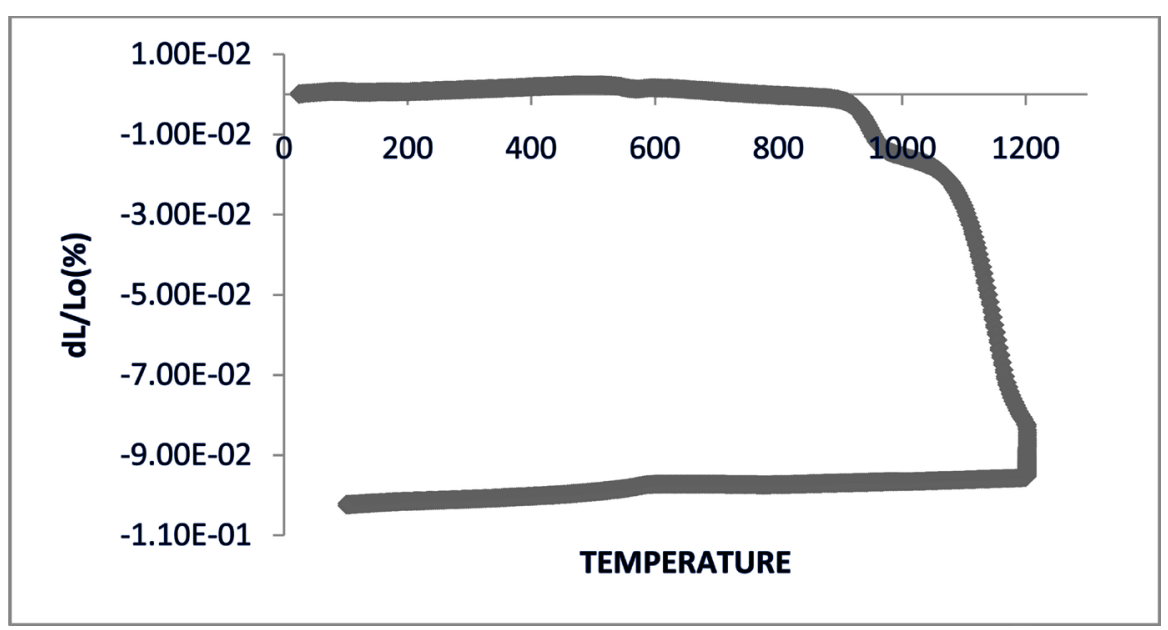

Figure 13. Dilatometric curve of MOU.

The analysis of this curve reveals:

- A light (low) dilatation until $570^{\circ} \mathrm{C}$.

- A shrinkage between $550^{\circ} \mathrm{C}$ and $600^{\circ} \mathrm{C}$. 
- An increasing shrinkage from $600^{\circ} \mathrm{C}$ to near $900^{\circ} \mathrm{C}$.

- A shrinkage between $900^{\circ} \mathrm{C}$ and $1000^{\circ} \mathrm{C}$ linked at an exothermic phenomenon.

- An intense shrinkage from $1000^{\circ} \mathrm{C}$ until $1200^{\circ} \mathrm{C}$.

- On the cooling curve, a peak at $575^{\circ} \mathrm{C}$ associated at the reversible transformation of quartz.

The shrinkage between $550^{\circ} \mathrm{C}$ and $600^{\circ} \mathrm{C}$ corresponds to the dehydroxylation of kaolinite for giving metakaolin. The diffusion of hydroxyl groups trends to bring together the plaques. That leads to an overall shrinkage.

The dilatometric curve from ambient temperature to $700^{\circ} \mathrm{C}$ is given on the Figure 14.

There is a low shrinkage to almost $100^{\circ} \mathrm{C}$ which was attributed to the departure of hygroscopic water. We observe a dilatation from $150^{\circ} \mathrm{C}$ to $487^{\circ} \mathrm{C}$ and from $490^{\circ} \mathrm{C}$ to $564^{\circ} \mathrm{C}$ shrinkage occurs. This last shrinkage is associated in the ATD curve at the dehydroxylation of kaolinite. Light withdrawal is induced by the dehydroxylation of the clay minerals mostly kaolinite. The dilation from ordinary temperature until near $600^{\circ} \mathrm{C}$, disturbed by some shrinkage, corresponds to the transformation quartz $\alpha$-quartz $\beta$. Quartz can reach an expansion of more than $1.7 \%$ at $580^{\circ} \mathrm{C}$ [47]. In MOU sample, we have that a dilatation of $0.2 \%$ only. This is justified by the abundance of kaolinite. Between $564^{\circ} \mathrm{C}$ and $587^{\circ} \mathrm{C}$ there is a dilation that indicates the quartz $\beta$, $\alpha$ transformation of quartz $\alpha$. From $600^{\circ} \mathrm{C}$ to around $900^{\circ} \mathrm{C}$, a progressive withdrawal is observed. The structural reorganization of the metakaolinite occurred between $900^{\circ} \mathrm{C}$ and $1000^{\circ} \mathrm{C}$ by a significant withdrawal. From approximately $1080^{\circ} \mathrm{C}$ at $1174^{\circ} \mathrm{C}$ the largest shrinkage is achieved. Fast sintering observed for the MOU material above $1050^{\circ} \mathrm{C}$ suggests the formation of a significant amount of viscous. The illite having some melting power might produce a liquid flow (stream) [48]. Comparing the dilatometric curve of MOUY with those carried out by Nana Koumtondji Lecomte [48] for different kaolinite-muscovite compositions, we can deduce that the dilatometric

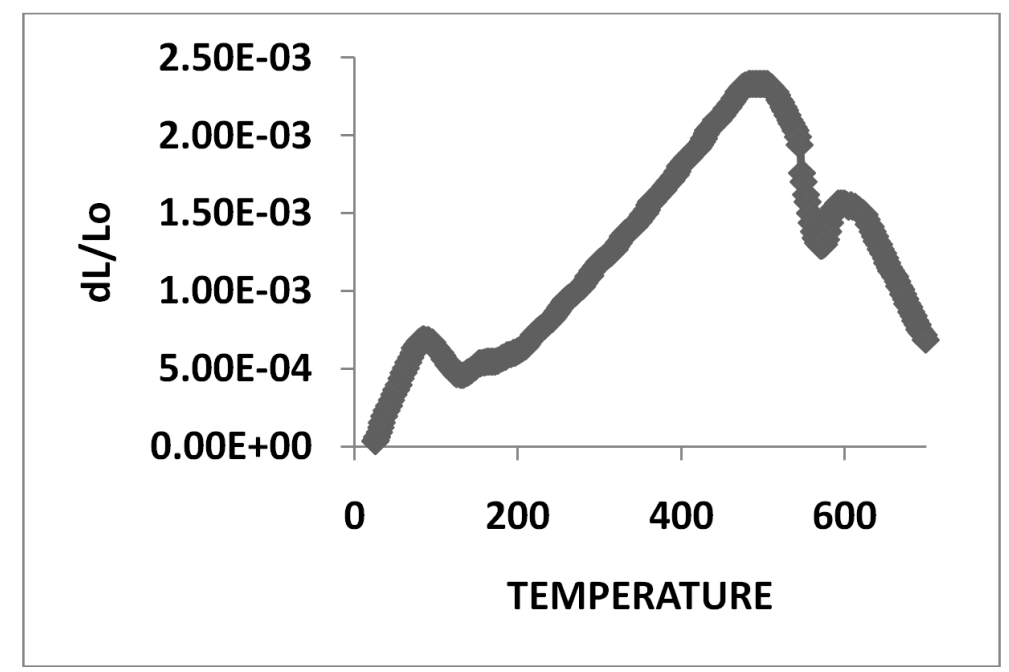

Figure $14.0^{\circ} \mathrm{C}-700^{\circ} \mathrm{C}$ range of dilatometry curve of MOU sample. 


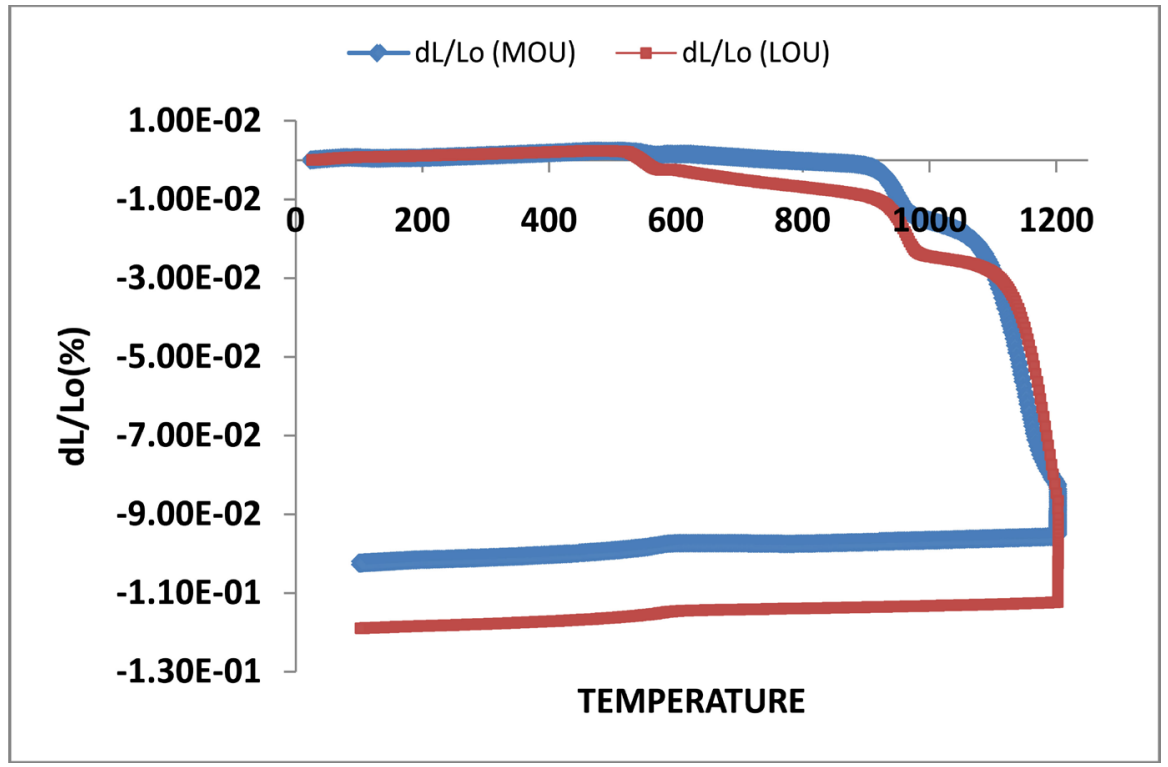

Figure 15. Comparison of dilatometric curves of MOU and LOU samples.

behavior is dominated by kaolinite. Indeed it was not observed dilatation of the network of the muscovite at temperatures below $1000^{\circ} \mathrm{C}$. This suggests that the illite has a composition that is less than $10 \%$, confirming the results of the mineralogical balance.

The comparison of the dilatometric curve of MOU with LOU's which has lower quartz content is given in Figure 15.

Relatively low shrinkage in MOU compared that of LOU resulted in the highest rate of quartz in MOU. The abundant presence of quartz (33\%), which, as long as it is not dissolved in the stream, form a rigid percolating skeleton that opposes the densification, thus justifying a weak shrinkage [41].

\subsection{Technological Properties}

Figure 16(a) and Figure 16(b) give us the evolution of technological properties:

- water absorption and the apparent density

- open porosity, flexural strength and linear shrinkage

The rate of absorption and the open porosity curves have the same trends. They decrease quickly from $1000^{\circ} \mathrm{C}$ to $1200^{\circ} \mathrm{C}$ when they reach a minimum. The minimum absorption rate is $2.5 \%$ then the minimum value of the open porosity is $6.02 \%$. These values are comparable with LOU. Despite the rate of quartz in MOUY, the gresification favored by the presence of fusible material allows significantly reduce the open porosity and rate of water absorption. The apparent density increases to a maximum at $1200^{\circ} \mathrm{C}$ and decreases beyond this temperature. The linear shrinkage moves up a level from $1200^{\circ} \mathrm{C}$. the maximum is $5.5 \%$. The flexural strength increases up to $1150^{\circ} \mathrm{C}(15 \mathrm{MPa})$, with a slight drop at $1200^{\circ} \mathrm{C}$ and dates back to $1250^{\circ} \mathrm{C}(16 \mathrm{MPa})$

Gresification parameters (water absorption, open porosity, linear shrinkage 


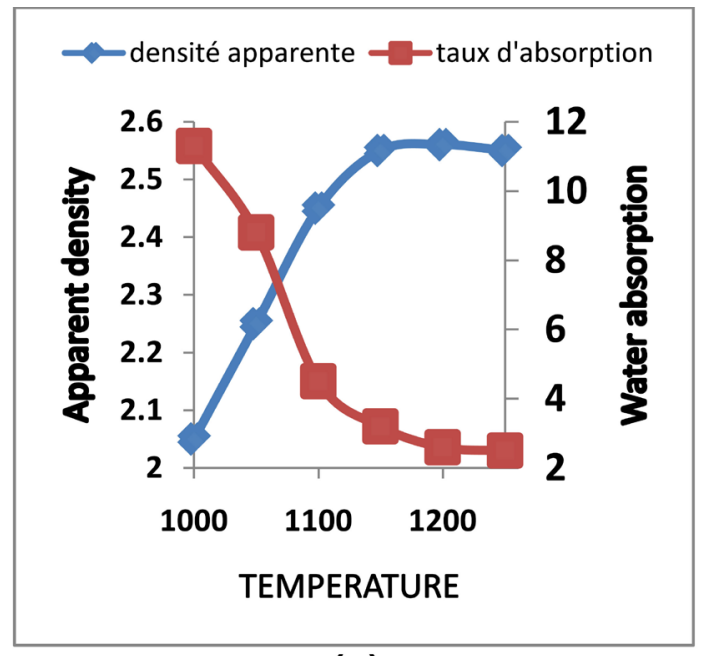

(a)

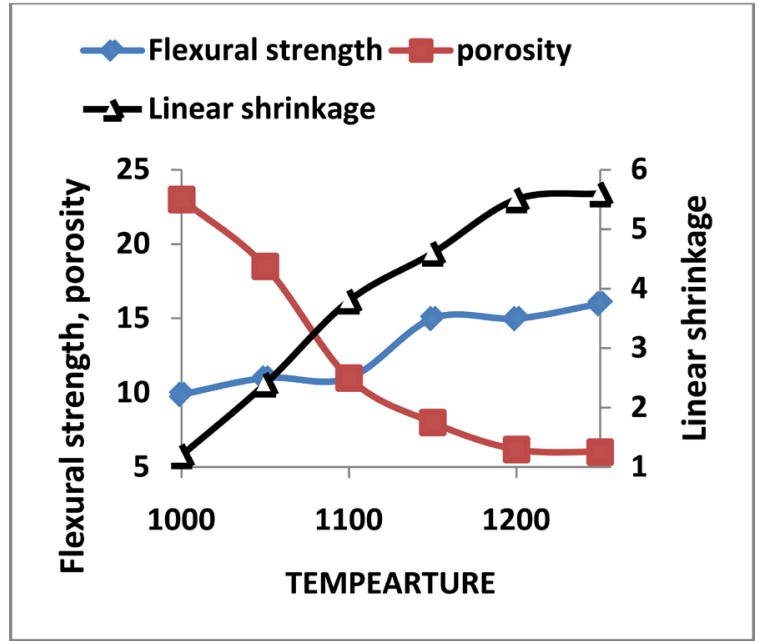

(b)

Figure 16. Evolution of technological properties with temperature.

and apparent density) indicate maximum densification around $1200^{\circ} \mathrm{C}$. The field of optimum sintering is reached when the open porosity reaches the minimum while the shrinkage its maximum. Beyond $1200^{\circ} \mathrm{C}$ the sintered material knows expansion characterized by the decrease in density. Two causes for this phenomenon are proposed:

- The presence of the cristobalite that appears at these temperatures [4] would cause a dilatation of the material [4] [49].

- This expansion can be explained also by the pressure of the gas in closed pores, which tends to expand the pores [48] [50].

Sintering is defined as the consolidation under the action of heat from one medium dispersed without total melting of the material. This consolidation is often accompanied by an increase of the density which translates by shrinkage [41]. We can observe an increase of the linear shrinkage in the temperature interval explored. Optimal and progressive particle rearrangement results in a withdrawal growing $(1.20 \%-5.60 \%)$. Taking into account enough strong slope 
of the curve of withdrawal depending on the firing temperature, we can consider a fast growth of the withdrawal reflecting an intense densification. The appearance of open porosity in the fired material could be promoted by different causes, such as the air trapped in the ceramic mud; formation of empty spaces in the different stages of drying; gases released during the thermal decomposition of carbonates or by the release of gases dissolved in quartz particles. At lower temperatures, only the open porosity predominates [50]. When the firing temperature increases, the capillary pressure due to the surface tension of the liquid phase tends to approach the particles, which in turn transforms the porosity of porous open to closed porosity, which is formed of spherical and isolated pores large. When the densification is reached, the porosity reaches its minimum value [50].

However, the water absorption is an indicator of classification of clayey materials: it allows defining the areas of use of materials. According to the Brazilian and Indian norms [51]:

- if water absorption $>25 \%$ Clay is suitable for the manufacture of refractories

- if $25 \%>$ water absorption $>20 \%$, the clay is indicated for the production of baked bricks

- if water absorption $<20 \%$, the clay is suitable for the manufacture of the tiles MOU clay would be suitable for the manufacture of the tiles.

Dondi et al. established the typology of ceramic tiles based on the water absorption and rate of iron oxides [7]. Taking into account the water absorption $(\sim 2 \%)$ and the $\mathrm{Fe}_{2} \mathrm{O}_{3}$ content (1.63\%), MOU is ranked in the common area between GWS (glazed white stoneware) and KLK (klinker) type. MOU complies with manufacturing both of a glazed white stoneware (GWS) and a klinker (KLK). The requirement of the rupture module $23 \mathrm{MPa}$ for the klinker and 30 $\mathrm{MPa}$ for the GWS [7] could not be reached. Indeed, the flexural strength of $\mathrm{MOU}$ to $1150^{\circ} \mathrm{C}(15 \mathrm{MPa})$ is below these requirements. The gap between the resulting flexural strength and the requirements of the GWS or KLK while other parameters are consistent is certainly due to structural or columnar defects. The figure gives us the classification of light-firing clays according to their amounts of minerals of the kaolinite group and the clayey fraction as well of their plasticity index.

Considering the kaolinite estimated content (44.41\%) and with a clayey fraction of 65\%, MOU would be classified as Ball Clays. Plasticity index (28.9) indicates that MOU is medium ball clays (BC1). The content of kaolinite obtained from the loss of weight corresponding to kaolinite dehydroxylation would be higher than $50 \%$. In this case MOU lies in the common area between BC and LK. (Low-grade Kaolins).

\section{Conclusions}

The objective of this work was to characterize clay extracted in Bouenza Department specifically in the locality of Nzaou in order to estimate in a first time 
its possibilities of use in the ceramic.

The illite and kaolinite were able to be highlighted as clay species. Quartz, anatase and rutile are the main impurities in the clay. The MOU clay is of medium plasticity and has a clay texture. The optimum temperature of sintering has been determined $\left(1150^{\circ} \mathrm{C}\right)$. The apparent density $(2.6)$, the linear withdrawal to cooking (5.7), open porosity (6\%), the rate of water absorption (2.6\%) and the resistance to bending $(16 \mathrm{MPa})$ have been achieved at the temperature of $1200^{\circ} \mathrm{C}$.

Clay proved to be used as glazed white stoneware (GWS) therefore for manufacturing the floor tiles and in the manufacture of clinkers. From the point of view of its plasticity, it can serve in the composition of ceramic pasta like medium ball clays.

We plan to improve the mechanical resistance. Indeed, as the flow obtained from illite which can play the role of flux is not enough for favor the densification, the influence of the addition of feldspar on the mechanical resistance and porosity open as well as the absorption rate will be studied for determining the conditions of improvement the densification therefore the mechanical resistance and studying the possibility to reduce the porosity at a value inferior to $1 \%$.

\section{Acknowledgements}

The DRX, ATD and ATG were realized in The Institute of condensated matter chemistry at Bordeaux (France). The authors are grateful to Jean-Pierre Chaminade, Denux and members of this institute. We also thank the BCBTP officials who have allowed us to achieve limits d'Atterberg.

\section{References}

[1] Chang, L.L.Y. (2002) Industrial Mineralogy: Materials, Processes, and Uses. Prentice Hall, Upper Saddle River.

[2] Grim, R. (1960) Some Applications of Clay Mineralogy. Journal of the Mineralogical Society of America, 45, 259-269.

[3] Baccour, H., Medhioubb, M., Jamoussic, F., Mhiria, T. and Daouda, A. (2008) Mineralogical Evaluation and Industrial Applications of the Triassic Clay Deposits, Southern Tunisia. Materials Characterization, 59, 1613-1622. https://doi.org/10.1016/j.matchar.2008.02.008

[4] Moutou, J.M., Mbedi, R., Elimbi, A., Njopwouo, D., Yvon, J., Barres, O. and Ntekela, H.R. (2012) Mineralogy and Thermal Behaviour of the Kaolinitic Clay of Loutété (Congo-Brazzaville). Research Journal of Environmental and Earth Sciences, 4, 316324.

[5] Celik, H. (2010) Technological Characterization and Industrial Application of Two Turkish Clays for the Ceramic Industry. Applied Clay Science, 50, 245-254. https://doi.org/10.1016/j.clay.2010.08.005

[6] de Oliveira Modesto, C. and Michael Bernardin, A. (2008) Determination of Plasticity. Applied Clay Science, 40, 15-19.

[7] Dondi, M., Raimondo, M. and Zanelli, C. (2014) Clays and Bodies for Ceramic Tiles: Reappraisal and Technological Classification. Applied Clay Science, 96, 91- 
109. https://doi.org/10.1016/j.clay.2014.01.013

[8] CERGEC (2013) Carte topographique du district de Mouyondzi réalisée à partir de la carte topographique du Congo, IGN France, Paris 19993, Echelle 1/100000, Projection: UTM, WGS 84.

[9] Martin, G. (1970) Cahiers ORSTOM série Pédol. Vol. 8, No. 1.

[10] de Boissezon, P. and Gras, F. (1970) Notice Explicative $\mathrm{N}^{\circ} 44$ Carte pédologique Sibiti-Est, République du Congo ORSTOM. 155 p.

[11] NF P 94-051 (1993) Détermination des limites d'Atterberg. AFNOR.

[12] NF X 31-107 (2003) Soil Quality—Particle Size Determination by SedimentationPipette Method. AFNOR.

[13] Carignan, J., Hild, P., Mevelle, G., Morel, J. and Yeghicheyan, D. (2001) Routine Analyses of Trace Elements in Geological Samples using Flow Injection and Low Pressure On-Line Liquid Chromatography Coupled to ICP-MS: A Study of Geochemical Reference Materials, BR, DR-N, UB-N, AN-G and GH. Geostandards Newsletter, 25, 187-198. https://doi.org/10.1111/j.1751-908X.2001.tb00595.x

[14] NF ISO 10694 (1995) Soil Quality-Determination of Organic and Total Carbon after Dry Combustion (Elementary Analysis) NF ISO 13878-1998 Soil Quality-Determination of Total Nitrogen Content by Dry Combustion (Elemental Analysis).

[15] NF X 31-130 (1999) Soil Quality-Chemical Methods-Determination of Cationic Exchange Capacity (CEC) and Extractible Cations AFNOR.

[16] NF P18-554 (1979) Mesures des masses volumiques, porosité, coefficient d'absorption d'eau et en teneur en eau des gravillons et cailloux. Décembre.

[17] Aliprandi, G. (1979) Matériaux réfractaires et céramiques techniques. Edition Septima, Paris, $612 \mathrm{p}$.

[18] Houmba, P. (1987) Etude d'un matériau céramique industriel: Transformations physiques et minéralogiques en fonction de la température et de l'atmosphère de cuisson. PhD Thesis, Université Louis Pasteur, Strasbourg.

[19] United States Department of Agriculture (1993) Soil Survey Manual. Soil Conservation Service Soil Survey Division Staff, Handbook 18.

[20] Dondi, M., Fabbri, B. and Laviano, R. (1992) Characteristics of the Clays Utilized in the Brick Industry in Apulia and Basilicata (Southern Italy). Mineralogica et Petrographica Acta, 35, 181-191.

[21] Casagrande, A. (1948) Classification and Identification of Soils. Transactions of the American Society of Civil Engineers, 113, 901-930.

[22] Holtz, R.D. and Kovacs, W.D. (1981) An Introduction to Geotechnical Engineering. Prentice Hall, Englewood.

[23] Bain, J.A. and Highly, D.E. (1978) Regional Appraisal of Clay Resources: Challenge to the Clay Mineralogist. In: Mortland, M.M. and Faxmer, V.C., Eds., Proceedings of the International Clay Conference, Elsevier, Amsterdam, 437-446.

[24] Brindley, G.W. and Brown, G. (1980) Crystal Structures of Clay Minerals and Their Identification. Mineralogical Society, London, $497 \mathrm{p}$.

[25] Caillère, S., Hénin, S. and Rautureau, M. (1982) Minéralogie des argiles. Vol. 1, Masson, $184 \mathrm{p}$.

[26] Frost, R.L. and Johansson, U. (1998) Combination Bands in the Infrared Spectroscopy of Kaolins-A Drift Spectroscopy Study. Clays and Lay Minerals, 46, 466477.

[27] Farmer, V.C. and Russel, J.D. (1964) The Infrared Spectra of Layer Silicates. Spec- 
trochimica Acta, 20, 1149-1173.

[28] Van Olphen, H. and Frippiat, J.J. (1979) Data Handbook for Clay Minerals and Other Non Metallic Minerals. Pergamon Press, London.

[29] Frost, R.L. and van der Gaast, S.J. (1997) Kaolinite Hydroxyls-A Raman Microscopy Study. Clay Minerals, 32, 293-306. https://doi.org/10.1180/claymin.1997.032.3.09

[30] Njopwouo, D. (1984) Minéralogie et physico-chimie des argiles de Bomkoul et de Balengou (Cameroun): Utilisation dans la polymérisation du styrène et dans le renforcement du caoutchouc naturel. Thèse de Doctorat d'Etat, Université de Yaoundé, Cameroun, 300 p.

[31] Bich, Ch., Ambroise, J. and Péra, J. (2009) Influence of Degree of Dehydroxylation on the Pozzolanic Activity of Metakaolin. Applied Clay Science, 44, 194-200. https://doi.org/10.1016/j.clay.2009.01.014

[32] Kakali, G., Perraki, T., Tsivillis, S. and Badogiannis, E. (2001) Thermal Treatment of Kaolin: The Effect of Mineralogy on the Pozzolanic Activity. Applied Clay Science, 20, 73-80. https://doi.org/10.1016/S0169-1317(01)00040-0

[33] Frost, R.L. (1998) Hydroxyl Deformation in Kaolins. Clays and Clay Minerals, 46, 280-289. https://doi.org/10.1346/CCMN.1998.0460307

[34] Saikia, N.J., Bharali, D.J., Sengupta, P., Bordoloi, D., Goswamee, R.L., Saikia, P.C. and Borthakur, P.C. (2003) Characterization, Beneficiation and Utilization of a Kaolinite Clay from Assam. India Applied Clay Science, 24, 93-103. https://doi.org/10.1016/S0169-1317(03)00151-0

[35] Frost, R.L. and Vassallo, A.M. (1996) The Dehydroxylation of the Kaolinite Clay Minerals using Infrared Emission Spectroscopy. Clays and Clay Minerals, 44, 635-651. https://doi.org/10.1346/CCMN.1996.0440506

[36] Lappi, S.E., Brandye, S. and Franzen, S. (2004) Infrared Spectra of $\mathrm{H}_{2}{ }^{16} \mathrm{O}, \mathrm{H}_{2}{ }^{18} \mathrm{O}$ and $\mathrm{D}_{2} \mathrm{O}$ in the Liquid Phase by Single-Pass Attenuated Total Internal Reflection Spectroscopy. Spectrochimica Acta, Part A, 60, 2611-2619. https://doi.org/10.1016/j.saa.2003.12.042

[37] Hajjaji, M., Kacim, S., Alami, A., El Bouadili, A. and El Mountassir, M. (2001) Chemical and Mineralogical Characterization of a Clay Taken from the Morrocan Meseta and a Study of Interaction between Its Fine Fraction and Methylene Blue. Applied Clay Science, 20, 1-12. https://doi.org/10.1016/S0169-1317(00)00041-7

[38] Mackenzie, R.C. (1957) The Differential Thermal Investigation of Clays. The Mineralogical Society (Clay Mineral Group), London, $456 \mathrm{p}$.

[39] Jouenne, C.A. (2001) Traité de céramiques et matériaux minéraux. Edition Septima, Paris, $657 \mathrm{p}$.

[40] Kabre, T.S., Traore, K. and Blanchart, P. (1998) Mineralogy of Clay Raw Material from Burkina Faso and Niger Used for Ceramic Wares. Applied Clay Science, 12, 463-477. https://doi.org/10.1016/S0169-1317(98)00005-2

[41] Pialy, P. (2009) Étude de quelques matériaux argileux du site de Lembo (Cameroun): Minéralogie, comportement au frittage et analyse des propriétés d'élasticité. Thèse de Doctorat, Université de Limoges, Limoges, 147 p.

[42] Soro, N.S. (2003) Influence des ions fer sur les transformations thermiques de la kaolinite. Thèse de doctorat, Université de Limoges, Limoges.

[43] Jeanroy, E. (1983) Diagnostic des formes du fer dans les pédogénèses tempérées. Thèse de Docteur d’Université, Université Nancy I, Nancy, 157 p.

[44] Bertolino, L.C., Malta Rossi, A., Scorzelli, R.B. and Torem, M.L. (2010) Influence of 
Iron on Kaolin Whiteness: An Electron Paramagnetic Resonance Study. Applied Clay Science, 49, 170-175. https://doi.org/10.1016/j.clay.2010.04.022

[45] Yvon, J., Baudracco, J., Cases, J.M. and Weiss, J. (1990) Eléments de minéralogie quantitative en microanalyse des argiles. In: Deccareau, A., Ed., Matériaux Argileux, Structures, Propriétés et Applications, SFMC-GFA, Paris, Partie IV, Chap. 3, 473-489.

[46] Fiori, C., Fabbri, B., Donati, F. and Venturi, I. (1989) Mineralogical Composition of the Clay Bodies Used in the Italian Tile Industry. Applied Clay Science, 4, 461-473. https://doi.org/10.1016/0169-1317(89)90023-9

[47] Zitano, I. (2003-2004) Comportamento dilatometrico e trasformazioni ad alta temperature delle materie prime ceramiche, tesi di laurea. Universita degli studi di Modena e Reggio Emilia.

[48] Nana Koumtondji Lecomte Gisèle Laure (2004) Transformations thermiques, organisation structurale et frittage des composés kaolinite. Thèse de doctorat, Limoges, $214 \mathrm{p}$.

[49] Elimbi, A., Founyape, S. and Njopwouo, D. (2004) Effets de la température de cuisson sur la composition minéralogique et les propriétés physiques et mécaniques de deux matériaux du gisement argileux de Bakong. Annales de Chimie Science des Matériaux, 29, 67-77. https://doi.org/10.3166/acsm.29.2.67-77

[50] Romero, M., Andrès, A., Alonso, R., Viguri, J. and Rincon, J.M. (2008) Sintering Behaviour of Ceramic Bodies from Contaminated Marine Sediments. Ceramics International, 34, 1917-1924. https://doi.org/10.1016/j.ceramint.2007.07.002

[51] Monteiro, S.N. and Vieira, C.M.F. (2004) Influence of Firing Temperature on the Ceramic Properties of Clays from Campos dos Goytacazes, Brazil. Applied Clay Science, 27, 229-234. https://doi.org/10.1016/j.clay.2004.03.002 